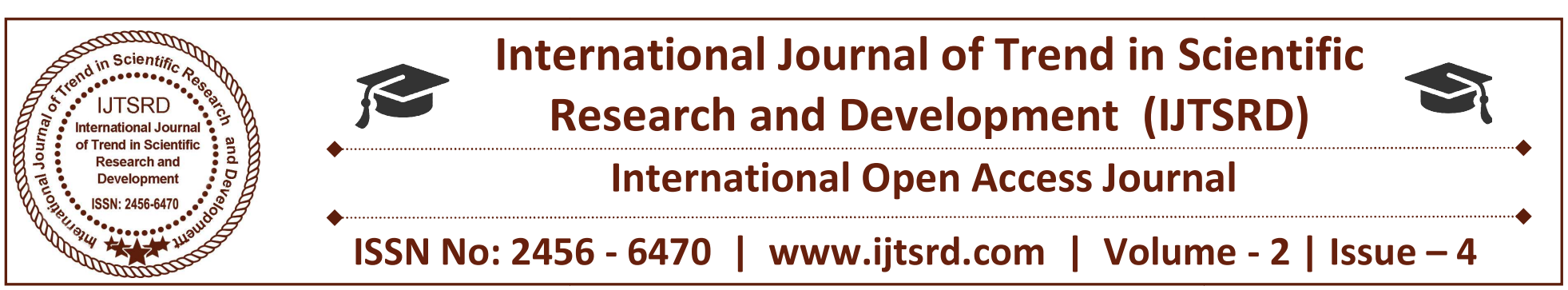

\title{
Does Corporate Governance influence Firms' Financial Performance? - A Study of Indian Nifty Fifty
}

\author{
Dr. Yashasvi Rajpara \\ Assistant Professor, SGM (Eng. Med.) College of Commerce \& Management (SEMCOM) \\ Affiliated to Sardar Patel University, Vallabh Vidyanagar, Gujarat, India
}

\section{ABSTRACT}

Corporate Governance brings about equilibrium between the expectations of the owners, employees, customers and all other stakeholders and it extends beyond corporate law. Its fundamental objective is not mere fulfillment of the requirement of the law but to ensure commitment of the Board in managing the company in a transparent manner for maximizing shareholder value. Non - compliance of the Corporate Governance Code results into heavy Penalties, punishment and loss of repudiation which may spoil the image and may affect the financial performance and valuation of the firm. In view of the above, the present study wants to find out the effect of compliance of Corporate Governance Code on the Financial Performance of the Selected Listed Companies of India. With a view to examining improvement in compliance of corporate governance in sample listed companies a quality check model has been developed. For this purpose, data related to the various indicators defining the corporate governance compliances have been taken into consideration in quality check model and score have been assigned to this indicators based on their relevance. In order to find the impact of corporate governance on financial performance of sample listed companies corporate governance score and indicators of financial performances i.e. Net Profit, Earnings before Interest, Tax, Depreciation and adjustments (EBITDA), Earnings Per Share (EPS), Net Worth and Market Value have been tested.

Keywords: Corporate Governance, Financial
Performance

\section{INTRODUCTION}

Corporate Governance may be defined as a set of systems, processes and principles which ensure that a company is governed in the best interest of all stakeholders. It is the system by which companies are directed and controlled. It is about promoting corporate fairness, transparency and accountability. In other words, 'good corporate governance' is simply 'good business'. It ensures: adequate disclosures and effective decision making to achieve corporate objectives, transparency in business transactions, statutory and legal compliances, and protection of shareholders' interests and commitment to values and ethical conduct of business for all its stakeholders. The aim of "Good Corporate Governance" is to ensure commitment of the board in managing the company in a transparent manner for maximizing long-term value of the company for its shareholders and all other partners. It integrates all the participants involved in a process, which is economic, and at the same time social. The root of the word governance is from 'gubernate', which means to steer. Corporate Governance would mean to steer an organization in the desired direction.

\section{Literature Review:}

Dave, Manisha et al. (2012), found positive relationship between governance and firm performance and it also studied the correlation between the Corporate Governance and firm's performance.

Azim (2012), used Structural Equation Modeling (SEM) and observed that some governance 
mechanisms have positive covariance, while some have negative covariance. Thus, he arrived at no consistent and significant relationship between governance mechanisms and financial performance (as proxied by ROE, ROA, Market to Book Value Ratio, Price - Earnings Ratio and Dividend Yield).

Balasubramanium et al. (2008), found a positive and statistically significant association between their overall India Corporate Governance Index (ICGI) and Tobin's Q value (used as proxy for market value of firm) and further this association was stronger for more profitable firms and firms with higher growth prospects.

Gompers et al. (2003), performed their study using governance index for 1500 large US firms, and found that the risk-adjusted returns of firms with strong governance were $8.5 \%$ higher than firms with poor governance.

Brown and Caylor (2004), found positive association between corporate governance scores and financial performance of firm (based on dividend payout, yield, profitability and shareholder returns).

However, some of the researchers have found that financial performance and corporate governance are independent to each other. Eisenhofer (2010) concluded that, "good corporate governance fosters long-term profitability. However, Core et al. (2006) and Statman and Gluskhov (2009), found no significant association between governance and financial performance. Van de Velde et al. (2005), have also come up with a similar conclusion in their study i.e., they found a positive but not significant relationship between corporate governance and financial performance of companies.

\section{$\underline{\text { Research Methodology: }}$}

The researcher has used empirical research method to examine impact of corporate governance practices on financial performance of selected companies in India. It involves quality check of compliances of corporate governance code, analysis and interpretation of data, findings, conclusion of the study and future scope of research.

\section{(i) Research Gap:}

In various research Corporate Governance Code and its impact on financial performance is taken into consideration but it does not include valuation part. Further it has been noted that majority researchers have compared its impact with one particular financial year but this study corporate governance compliances and financial parameters of two financial years i.e. 2014-15 and 2015-16. The selection of financial year 2014-15 and 2015-16 is made as there are two major changes in the year 2014 and 2015 in corporate governance code which may affect financial performance of company.

Revised clause 49 applicable from 1st October,2014 for financial year 2014-15 and Listing Obligations and Disclosure Requirements Regulations, 2015 (LODR) applicable as on 2nd September, 2015 for financial year 2015-16.

\section{(ii) Scope of the Study:}

Here researcher has selected Nifty Fifty Companies for the purpose of Study, financial performance is also a wider term but this study covers five financial performance indicators i.e. Net Profit, Earnings before Interest, Tax, Depreciation and adjustments (EBITDA), Earnings Per Share (EPS), Net Worth and Market Value.

The present study has used secondary source for data needed for analysis to achieve its objectives. Here, researcher has used deliberate/purposive/nonprobability Sampling method to collect data from secondary sources.

\section{(iii) Objectives of the Study}

In order to achieve the broad objective i.e., to examine impact of corporate governance on financial performance, the researcher has decomposed it into the following sub-objectives.

- To analyze the Corporate Governance Codes given by the various committees with a comparative perspective.

- To investigate the extent to which the selected companies under the study are practicing the given Codes of Corporate Governance or provisions of Clause-49 of SEBI.

- To develop a quality check model and find out whether the Compliances of Corporate Governance made by the companies under consideration are excellent, fair, or poor.

- To find out co-relation between Compliance of Corporate Governance Code and financial performance in the selected listed companies. 
- To find out the impact of Compliance of Corporate selected listed companies.

Governance Code on the financial performance in the

\section{(iv) Hypotheses}

H01: Majority of the corporate governance compliances made by the sample listed companies of the present study are of poor quality.

H11: Majority of the corporate governance compliances made by the sample listed companies selected of the present study are of good quality.

H02: There is no Positive correlation between compliance of corporate governance code and financial performance in the sample listed companies of the present study.

H12: There is positive correlation between compliance of corporate governance code and financial performance in the sample listed companies of the present study.

H03: Improvement in Corporate Governance Score and improvement in Net Profit are independent of each other.

H13: Improvement in Net Profit is dependent on improvement in Corporate Governance Score.

H04: Improvement in Corporate Governance Score and improvement in EBITDA are independent of each other.

H14: Improvement in EBITDA is dependent on improvement in Corporate Governance Score.

H05: Improvement in Corporate Governance Score and improvement in Earnings Per Share (EPS) are independent of each other.

H15: Improvement in Earnings Per Share (EPS) is dependent on improvement in Corporate Governance Score.

H06: Improvement in Corporate Governance Score and improvement in Net Worth are independent of each other.

H16: Improvement in Net Worth is dependent on improvement in Corporate Governance Score.

H07: Improvement in Corporate Governance Score and improvement in Market Value are independent of each other.

H17: Improvement in Market Value is dependent on improvement in Corporate Governance Score.

\section{Quality Check Model}

Quality Check model has been prepared to check the compliance of Corporate Governance of NSE Nifty 50 Companies for the year 2015-16. This model has been prepared on the basis of Revised clause 49 and Listing Obligations and Disclosure Requirements Regulations, 2015 (LODR) applicable as on 2nd September, 2015. The first part of model contains Statement of Company's philosophy on code of governance and display of it on company's website and in annual report in the section of corporate governance report. The second part of the model revels provisions for composition of Board i.e. appointment of woman director, Chairman \& CEO Independentness, Disclosure of tenure and age limit of directors, Disclosure of meaning of independent director and financial expert, Selection Criteria of Board of Directors including independent directors, Post Board meeting follow up system and compliance of the board procedures, appointment of lead independent director and Compliance Certification from $\mathrm{CEO}$ or $\mathrm{CFO}$ to the Board of Directors. It also contains provisions of remuneration policy and code of conduct for the board. The third part of model contains provisions for various Board Committees i.e. Audit Committee, Remuneration / Compensation Committee, Stakeholder's Relationship Committee, Nomination Committee and other committees like Health, Safety \& Environment Committee, Ethics and Compliance Committee, Investment Committee and Securities Transfer Committee. The fourth part of a model consists of provisions of other mandatory disclosures i.e. significant related party transactions having potential conflicts with the interest of the company, approval, review and disclosure of such related party transactions in corporate governance report, Non Compliance related to capital market matters during last three years, Proceeds from Public issues, Rights issues, Preferential issues, Management Discussion and Analysis, Shareholders' Information and Rights, Training to Board members, Evaluation of Non-Executive Directors, Accounting treatment and audit qualification and Whistle Blower Policy. Last 
part of the model includes provisions of General Body Meeting, Means and Communication of Shareholder's information, Disclosure of stakeholder's interest, CEO / CFO Certification and Compliance of Corporate Governance and Auditors' Certificate and other requirements i.e. The listed entity shall submit a quarterly compliance report on corporate governance in the format as specified by the Board from time to time to the recognized stock exchange(s) within fifteen days from close of the quarter, Details of all material transactions with related parties shall be disclosed along with the report mentioned in clause (a) of sub-regulation (2) and The report mentioned in clause (a) of sub-regulation (2) shall be signed either by the compliance officer or the chief executive officer of the listed entity. The Summary of Corporate Governance Score of NSE 50 Company is as follows.

Table-1: Calculation for Likert Scale

\begin{tabular}{|l|c|c|c|}
\hline & $\begin{array}{c}\text { Corporate } \\
\text { Governance } \\
\text { Score }\end{array}$ & $\mathbf{2 0 1 5 - 1 6}$ & $\mathbf{2 0 1 4 - 1 5}$ \\
\hline Excellent & $100-105$ & 2 & 0 \\
\hline Very Good & $95-99$ & 26 & 15 \\
\hline Good & $90-94$ & 21 & 32 \\
\hline Average & Below 90 & 1 & 3 \\
\hline & Total & $\mathbf{5 0}$ & $\mathbf{5 0}$ \\
\hline
\end{tabular}

(Source: Researcher's own Calculation)

Table-1 presents data on compliance of corporate governance of sample listed companies considered in the present study. It is depicted from data that that, in the year 2014-15, not a single company comes under excellent category i.e., none of the companies has a score in the range of 100-105. However, in the year 201516 two companies are seen to come under this category. Further, in the year 2014-15 fifteen companies have made it to the 'Very Good Category' which means such companies have a score ranging between 95 and 100.Again in the year 2015-16 twenty six companies appear in this category. So, it was found from the above data that in 2014-15 total forty seven companies are seen to fall under Excellent, Very Good or Good Category and only three companies are found in average category. It is further noticed that in the year 2015-16 total forty nine companies are found under Excellent, Very Good or Good Category while only one company falls under Average Category. Thus, improvement has been found in the compliance of corporate governance of the sample listed companies in 2015-16 as compared to 2014-15. Hence, null hypothesis H01 is rejected establishing the fact that majority of the corporate governance compliances made by the sample listed companies are of good quality.

Co-relation between Corporate Governance and Financial Performance of Sample listed Companies

Table-2: Calculation of Co-relation between Corporate Governance and Financial Performance and Valuation in 2015-16

\begin{tabular}{|l|c|c|c|c|c|c|}
\hline & $\begin{array}{c}\text { Corporate } \\
\text { Governance } \\
\text { Score }\end{array}$ & $\begin{array}{c}\text { Net Profit } \\
\text { (In } \\
\text { Crore) }\end{array}$ & $\begin{array}{c}\text { EBITDA } \\
\text { (In } \\
\text { Crore) }\end{array}$ & $\begin{array}{c}\text { Earnings } \\
\text { Per } \\
\text { Share } \\
\text { (In Rs.) }\end{array}$ & $\begin{array}{c}\text { Net Worth } \\
\text { (Shareholder's } \\
\text { Fund)(In } \\
\text { Crore) }\end{array}$ & $\begin{array}{c}\text { Market } \\
\text { Value } \\
\text { (In } \\
\text { Rs.) }\end{array}$ \\
\hline $\begin{array}{l}\text { Corporate } \\
\text { Governance } \\
\text { Score }\end{array}$ & 1 & & & & & \\
\hline $\begin{array}{l}\text { Net Profit (In } \\
\text { Crore) }\end{array}$ & 0.0228 & 1 & 1 & & & \\
\hline $\begin{array}{l}\text { EBITDA (In } \\
\text { Crore) }\end{array}$ & 0.1010 & 0.4834 & 1 & & & \\
\hline
\end{tabular}


International Journal of Trend in Scientific Research and Development (IJTSRD) ISSN: 2456-6470

\begin{tabular}{|c|c|c|c|c|c|c|}
\hline $\begin{array}{l}\text { Earnings Per } \\
\text { Share (In Rs.) }\end{array}$ & -0.0705 & 0.1072 & 0.0657 & 1 & & \\
\hline $\begin{array}{l}\text { Net Worth } \\
\text { (Shareholder's } \\
\text { Fund) (In } \\
\text { Crore) }\end{array}$ & 0.1604 & 0.1904 & 0.7730 & -0.1415 & 1 & \\
\hline $\begin{array}{l}\text { Market Value } \\
\text { (In Rs.) }\end{array}$ & -0.0874 & -0.0800 & -0.2115 & 0.3184 & -0.2651 & 1 \\
\hline
\end{tabular}

(Source: Researcher's own Calculation)

Results of correlation analysis are presented in Table-2, it is found that there exists partial positive correlation between Corporate Governance Compliances and Financial Performances (measured in terms of net profit, earnings before interest, depreciation, Tax and adjustments, and net worth) of the sample listed companies. However, so far as valuation is concerned which is explained by Earning per Share and Market Value, a partial negative correlation is found between the two i.e., Corporate Governance Compliances and Financial Performances. Hence, except the two parameters related to valuation part explaining financial performance, so null hypothesis $\mathrm{HO2}$ is rejected which means there prevails partial positive correlation between compliance of corporate governance and financial performance of the sample listed company under study.

Table-3: Calculation of Co-relation between Corporate Governance and Financial Performance and Valuation in Sample listed Companies in 2014-15

\begin{tabular}{|c|c|c|c|c|c|c|}
\hline & $\begin{array}{c}\text { Corporate } \\
\text { Governance } \\
\text { Score }\end{array}$ & $\frac{\begin{array}{c}\text { Net Profit } \\
\text { (In }\end{array}}{\text { Crore) }}$ & $\begin{array}{c}\text { EBITDA } \\
(\text { In } \\
\text { Crore) }\end{array}$ & $\begin{array}{l}\text { Earnings } \\
\text { Per } \\
\text { Share } \\
\text { (In Rs.) }\end{array}$ & $\begin{array}{c}\text { Net Worth } \\
\text { (Shareholder's } \\
\text { Fund)(In } \\
\text { Crore) }\end{array}$ & $\begin{array}{c}\text { Market } \\
\text { Value } \\
\text { (In } \\
\text { Rs.) }\end{array}$ \\
\hline $\begin{array}{l}\text { Corporate } \\
\text { Governance Score }\end{array}$ & 10 & Resea & ch and & 8 & 8.8 & \\
\hline $\begin{array}{l}\text { Net Profit (In } \\
\text { Crore) }\end{array}$ & 0.0148 & DVel & prinent & 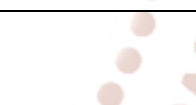 & & \\
\hline EBITDA (In Crore) & 0.1703 & $0.1754 \quad 2$ & $56=1 / 4$ & & & \\
\hline $\begin{array}{l}\text { Earnings Per Share } \\
\text { (In Rs.) }\end{array}$ & -0.1541 & 0.2619 & 0.0680 & & & \\
\hline $\begin{array}{l}\text { Net Worth } \\
\text { (Shareholder's } \\
\text { Fund) (In Crore) }\end{array}$ & 0.2096 & 0.0609 & 0.8894 & -0.0393 & 1 & \\
\hline $\begin{array}{l}\text { Market Value (In } \\
\text { Rs.) }\end{array}$ & -0.0747 & -0.1160 & -0.3147 & 0.2920 & -0.3218 & 1 \\
\hline
\end{tabular}

(Source: Researcher's own Calculation)

Results of correlation analysis are presented in Table-3, it is found that there exists partial positive correlation between Corporate Governance Compliances and Financial Performances (measured in terms of net profit, earnings before interest, depreciation, Tax and adjustments, and net worth) of the sample listed companies. However, so far as valuation is concerned which is explained by Earning per Share and Market Value, a partial negative correlation is found between the two i.e. Corporate Governance Compliances and Financial Performances. Hence, except the two parameters related to valuation part explaining financial performance, null hypothesis $\mathrm{HO2}$ is rejected which means there prevails partial positive correlation between compliance of corporate governance and financial performance of the sample listed company under study. 
Findings based on Co-relation:

Results of correlation analysis presented in Table-2 and Table-3 for the year of 2015-16 and 2014-15 found that there is partial positive correlation between Corporate Governance Compliances and Financial Performances but in valuation of sample listed companies it shows partial negative co-relation. It means there are other factors which may have more influence on valuation part.

Data Analysis

(i) Chi Square Test for effect of Changes in Corporate Governance Score on Net Profit in Sample listed Companies

Table-4: Observed Frequency Table

\begin{tabular}{|l|c|c|c|}
\hline & \multicolumn{2}{|c|}{ Profit Improved } & \\
\hline Corporate Governance Score & Yes & No & Total \\
\hline Score Improved & 23 & 13 & 36 \\
\hline Negative & 1 & 0 & 1 \\
\hline Neutral & 9 & 4 & 13 \\
\hline Total & 33 & 17 & 50 \\
\hline
\end{tabular}

(Source: Researcher's own Calculation)

Table-5: Calculation of Chi Square

\begin{tabular}{|c|c|c|c|c|}
\hline Fo & Fe & Fo-Fe & $($ Fo-Fe)2 & $($ Fo-Fe)2/Fe \\
\hline 23 & 23.76 & -0.76 & 0.5776 & 0.0243 \\
\hline 13 & 12.24 & 0.76 & 0.5776 & 0.0472 \\
\hline 1 & 0.66 & 0.34 & 0.1156 & 0.1752 \\
\hline 0 & 0.34 & -0.34 & 0.1156 & 0.3400 \\
\hline 9 & 8.58 & 0.42 & 0.1764 & 0.0206 \\
\hline 4 & 4.42 & -0.42 & 0.1764 & 0.0399 \\
\hline & & $S S N$ & $\begin{array}{c}\text { Chi Square } \\
\text { Calculated }\end{array}$ & $\mathbf{0 . 6 4 7 1}$ \\
\hline
\end{tabular}

(Source: Researcher's own Calculation)

Chi Square Tabulated for 2 Degrees of Freedom at 5\% Level of significance is 5.9915. As per the Chi Square calculation presented in Table, the calculated value is less than the tabulated value which means null H03 hypothesis is accepted. So, it can be concluded that improvement in Corporate Governance Score and improvement in Net Profit are independent of each other. This further means one does not have any relation with the other.

(ii) Chi Square Test for effect of Changes in Corporate Governance Score on EBITDA

Table-6: Observed Frequency Table

\begin{tabular}{|l|c|c|c|}
\hline & \multicolumn{2}{|c|}{$\begin{array}{c}\text { EBITDA } \\
\text { Improved }\end{array}$} & \\
\hline Corporate Governance Score & Yes & No & Total \\
\hline Score Improved & 26 & 10 & 36 \\
\hline Negative & 1 & 0 & 1 \\
\hline Neutral & 9 & 4 & 13 \\
\hline Total & 36 & 14 & 50 \\
\hline
\end{tabular}

(Source: Researcher's own Calculation) 
Table-7: Calculation of Chi Square

\begin{tabular}{|c|c|c|c|c|}
\hline Fo & Fe & Fo-Fe & $(\mathbf{F o}-\mathbf{F e}) 2$ & $(\mathbf{F o}-\mathbf{F e}) 2 / \mathbf{F e}$ \\
\hline 26 & 25.92 & 0.08 & 0.0064 & 0.0002 \\
\hline 10 & 10.08 & -0.08 & 0.0064 & 0.0006 \\
\hline 1 & 0.72 & 0.28 & 0.0784 & 0.1089 \\
\hline 0 & 0.28 & -0.28 & 0.0784 & 0.2800 \\
\hline 9 & 9.36 & -0.36 & 0.1296 & 0.0138 \\
\hline 4 & 3.64 & 0.36 & 0.1296 & 0.0356 \\
\hline & & & $\begin{array}{c}\text { Chi Square } \\
\text { Calculated }\end{array}$ & $\mathbf{0 . 4 3 9 2}$ \\
\hline
\end{tabular}

(Source: Researcher's own Calculation)

Chi Square Tabulated for 2 Degrees of Freedom at 5\% Level of significance is 5.9915. So, Here Chi square calculated value is less than tabulated value. So, null hypothesis H04 is accepted. So, it can be concluded that Improvement in Corporate Governance Score and improvement in EBITDA are independent of each other.

(iii) Chi Square Test for effect of Changes in Corporate Governance Score on EPS

Table-8: Observed Frequency Table

\begin{tabular}{|l|c|c|c|}
\hline & \multicolumn{2}{|c|}{ EPS Improved } & \\
\hline Corporate Governance Score & Yes & No & Total \\
\hline Score Improved & 21 & 15 & 36 \\
\hline Negative Internatio & 1 & 0 & 1 \\
\hline Neutral & 9 & 4 & 13 \\
\hline Total & 31 & 19 & 50 \\
\hline
\end{tabular}

(Source: Researcher's own Calculation)

Table-9: Calculation of Chi Square

\begin{tabular}{|c|c|c|c|c|}
\hline Fo & Fe & Fo-Fe & $(\mathbf{F o}-\mathbf{F e}) 2$ & $(\mathbf{F o}-\mathbf{F e}) 2 / \mathbf{F e}$ \\
\hline 21 & 22.32 & -1.32 & 1.742 & 0.078 \\
\hline 15 & 13.68 & 1.32 & 1.742 & 0.127 \\
\hline 1 & 0.62 & 0.38 & 0.144 & 0.233 \\
\hline 0 & 0.38 & -0.38 & 0.144 & 0.380 \\
\hline 9 & 8.06 & 0.94 & 0.884 & 0.110 \\
\hline 4 & 4.94 & -0.94 & 0.884 & 0.179 \\
\hline & & & $\begin{array}{c}\text { Chi Square } \\
\text { Calculated }\end{array}$ & $\mathbf{1 . 1 0 7}$ \\
\hline
\end{tabular}

(Source: Researcher's own Calculation)

Chi Square Tabulated for 2 Degrees of Freedom at 5\% Level of significance is 5.9915.So, Here Chi square calculated value is less than tabulated value. Therefore, null hypothesis H05 is accepted. So, it can be concluded that Improvement in Corporate Governance Score and improvement in Earnings Per Share (EPS) are independent of each other.

(iv) Chi Square Test for effect of Changes in Corporate Governance Score on Net Worth 
Table-10: Observed Frequency Table

\begin{tabular}{|c|c|c|c|}
\hline & \multicolumn{2}{|c|}{$\begin{array}{c}\text { Net Worth } \\
\text { Improved }\end{array}$} & \\
\hline Corporate Governance Score & Yes & No & Total \\
\hline Score Improved & 29 & 7 & 36 \\
\hline Negative & 1 & 0 & 1 \\
\hline Neutral & 12 & 1 & 13 \\
\hline Total & 42 & 8 & 50 \\
\hline
\end{tabular}

(Source: Researcher's own Calculation)

Table-11: Calculation of Chi Square

\begin{tabular}{|c|c|c|c|c|}
\hline Fo & Fe & Fo-Fe & (Fo-Fe)2 & $\begin{array}{c}(\mathbf{F o}- \\
\text { Fe)2/Fe }\end{array}$ \\
\hline 29 & 30.24 & -1.24 & 1.5376 & 0.0508 \\
\hline 7 & 5.76 & 1.24 & 1.5376 & 0.2669 \\
\hline 1 & 0.84 & 0.16 & 0.0256 & 0.0305 \\
\hline 0 & 0.16 & -0.16 & 0.0256 & 0.1600 \\
\hline 12 & 10.92 & 1.08 & 1.1664 & 0.1068 \\
\hline 1 & 2.08 & -1.08 & 1.1664 & 0.5608 \\
\hline$c$ & Intert & Chionat & $\begin{array}{c}\text { Chi Square } \\
\text { Calculated }\end{array}$ & $\mathbf{1 . 1 7 5 8}$ \\
\hline
\end{tabular}

(Source: Researcher's own Calculation)

Chi Square Tabulated for 2 Degrees of Freedom at 5\% Level of significance is 5.9915.So, Here Chi square calculated value is less than tabulated value. Hence, null hypothesis H06 is accepted. So, it can be concluded that Improvement in Corporate Governance Score and improvement in Net Worth are independent of each other.

(v) Chi Square Test for effect of Changes in Corporate Governance Score on Market Value Table-12: Observed Frequency Table

\begin{tabular}{|c|c|c|c|}
\hline & \multicolumn{2}{|c|}{$\begin{array}{c}\text { Market Value } \\
\text { Improved }\end{array}$} & \\
\hline Corporate Governance Score & Yes & No & Total \\
\hline Score Improved & 17 & 19 & 36 \\
\hline Negative & 0 & 1 & 1 \\
\hline Neutral & 6 & 7 & 13 \\
\hline Total & 23 & 27 & 50 \\
\hline
\end{tabular}

(Source: Researcher's own Calculation)

Table-13: Calculation of Chi Square

\begin{tabular}{|c|c|c|c|c|}
\hline Fo & Fe & Fo-Fe & $(\mathbf{F o - F e ) 2}$ & $(\mathbf{F o}-\mathbf{F e}) 2 / \mathbf{F e}$ \\
\hline 17 & 16.56 & 0.44 & 0.1936 & 0.0117 \\
\hline 19 & 19.44 & -0.44 & 0.1936 & 0.0100 \\
\hline 0 & 0.46 & -0.46 & 0.2116 & 0.4600 \\
\hline
\end{tabular}


International Journal of Trend in Scientific Research and Development (IJTSRD) ISSN: 2456-6470

\begin{tabular}{|l|c|c|c|c|}
1 & 0.54 & 0.46 & 0.2116 & 0.3919 \\
\hline 6 & 5.98 & 0.02 & 0.0004 & 0.0001 \\
\hline 7 & 7.02 & -0.02 & 0.0004 & 0.0001 \\
\hline & & & $\begin{array}{l}\text { Chi Square } \\
\text { Calculated }\end{array}$ & $\mathbf{0 . 8 7 3 6}$ \\
\hline
\end{tabular}

(Source: Researcher's own Calculation)

Chi Square Tabulated for 2 Degrees of Freedom at $5 \%$ Level of significance is 5.9915.So, Here Chi square calculated value is less than tabulated value. Thus, null hypothesis $\mathrm{HO} 7$ is accepted. So, it can be concluded that Improvement in Corporate Governance Score and improvement in Market Value are independent of each other.

\section{Findings on basis of Chi-Square analysis}

Result of Chi-Square analysis says that Corporate Governance Score and improvement in financial performance and valuation are independent of each other. It means other factors like industry trend, market condition, government policy, economic condition, consumer/ investor preference etc. may have more influence on financial performance and valuation of sample listed companies.

\section{Conclusion}

It is depicted from study that, in the year 2014-15, not a single company comes under excellent category i.e., none of the companies has a score in the range of 100105. However, in the year 2015-16 two companies are seen to come under this category. Further, in the year 2014-15 fifteen companies have made it to the 'Very Good Category' which means such companies have a score ranging between 95 and 100. Again in the year 2015-16 twenty six companies appear in this category. So, it was found from the above data that in 2014-15 total forty seven companies are seen to fall under Excellent, Very Good or Good Category and only three companies are found in average category. It is further noticed that in the year 2015-16 total forty nine companies are found under Excellent, Very Good or Good Category while only one company falls under Average Category. Thus, improvement has been found in the compliance of corporate governance of the sample listed companies in 2015-16 as compared to 2014-15.

It is found from the hypothesis testing that there exists partial positive correlation between Corporate
Governance Compliances and Financial Performances (measured in terms of net profit, earnings before interest, depreciation, Tax and adjustments, and net worth) of the sample listed companies. However, so far as valuation is concerned which is explained by Earning per Share and Market Value, a partial negative correlation is found between the two i.e., Corporate Governance Compliances and Financial Performances. Hence, except the two parameters related to valuation part explaining financial performance, null hypothesis is rejected which means there prevails partial positive correlation between compliance of corporate governance and financial performance of the sample listed company under study.

Result of Chi-square analysis says that improvement in Corporate Governance Compliances and improvement in Financial Performance and Valuation are independent. Regular compliances of Corporate Governance create a loyalty in customers and it retains existing customers and attracts new customers. It also creates goodwill in the minds of the investors but there are other factors like industry trend, market condition, volume of industry, volume and scale of a company, customer preference, investor preference may affects the financial performance and valuation of firm.

\section{Future Scope of Study}

The present study mostly veered round examining the relationship between corporate governance practices and financial performance of companies. The study was entirely based on secondary data and the analysis and conclusion were drawn based on data derived mostly from the annual reports of the selected companies. However, in future, the study may also be extended to a cross examination wherein the researcher may include a primary survey of investors in order to find out the compatibility of results and confirmation from a more practical perspective. This paves the way to an extension of the present research work. The other extension of the study which may be 
brought by any researcher in future is relating corporate governance of the companies with dimensions other than financial performance. For instance, one may try to examine the relation of corporate governance of such companies with their HR policies, future growth prospects, technological advancement, horizontal and vertical expansion, market venturing, etc.

\section{$\underline{\text { References: }}$}

1) Azim, M. I. (2012), "Corporate Governance Mechanisms and their Impact on Company Performance: A Structural Equation Model Analysis", Australian Journal of Management, $37(3)$

2) Balasubramanian, N. (1999). "Changing Perceptions of Corporate Governance in India". ASCI Journal of Management, vol. 27 (1\&2).

3) Brown, L. D. \&Caylor, M. L. (2004), "Corporate Governance Study: The Correlation between Corporate Governance and Company Performance", Institutional Shareholder Services (ISS).

4) Retrieved from http://www.stybelpeabody.com/issscoresandshare holdervalue.pdf.

5) Core, J. E., Guay, W. R., \&Rusticus, T. O. (2006), "Does Weak Governance Cause Weak Stock Returns? An Examination of Firm Operating Performance and Investors' Expectations", The Journal of Finance, 61(2), pp.655-687.

6) Dave, Manisha et al. (2012), "Application of Clause 49 By Indian Listed Companies", Indian Journal of Accounting, vol. XLIII, Issue 1, pp. 7889.

7) Gompers, P., Ishii, J., \&Metrick, A. (2003), "Corporate Governance and Equity Prices" The Quarterly Journal of Economics, 118(1), pp.107156.

8) Eisenhofer, J. W. (2010), "Does Corporate Governance Matter to Investment Returns?", Retrieved from

9) http://www.gelaw.com/wpontent/uploads/2011/05/ART_004A_corp_governa nce colorchart.pdf.

10) Statman, M. D., \&Glushkov (2009). The Wages of Social Responsibility", Financial Analysts Journal, 65, pp.33-46.
11) Van de Velde, E., Vermeir, W., \&Corten, F. (2005), "Corporate Social Responsibility and Financial Performance", Corporate Governance (3), pp. 129-138.

\section{Books Referred}

12) Bajaj, P. S. and Raj Agarwal (2004). "Business Ethics: An Indian Perspective". New Delhi: Biztantra.

13) Governance, Business Ethics and Sustainability, The Institute of Company Secretaries of India, (2015).

14) Kapoor, N. D. (2004). "Corporate Laws and Secretarial Practice". New Delhi: Sultan Chand \& Sons.

15) Securities Laws and Regulation of Financial Markets, The Institute of Company Secretaries of India, (2015).

\section{Reports and other Publications Referred}

16) Corporate Governance Voluntary Guidelines (2009).Ministry of Corporate Affairs, Government of India.

17) Bhuva Ashish (2017), 'Impact of Corporate Governance on Financial Performance of Selected Companies in India', thesis submitted at Sardar Patel University.

18) Department of Company Affairs (2000). Report of the Task Force on Corporate Excellence through Governance.

19) Kumar Mangalam Birla Committee (1999). Report on Corporate Governance. Securities and Exchange Board of India

20) Narasimham Committee (1991). The Financial System Report.

21) Narayana Murthy Committee (2003). Report on Corporate Governance. SEBI.

22) Naresh Chandra Committee (2002). Report on Corporate Audit and Governance.

23) Naresh Chandra Committee (2009). Report of the CII Taskforce on Corporate Governance.

24) Revised Clause 49 and Listing Obligations and Disclosure Requirements Regulations, 2015 (LODR) applicable as on 2nd September, 2015

25) Securities and Exchange Board of India Clause 49 of Listing agreement. 